\title{
Cervical cancer mortality in Peru: regional trend analysis from 2008-2017
}

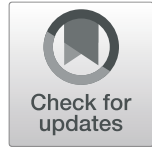

\author{
J. Smith Torres-Roman ${ }^{1,2^{*}}$ (D), Luz Ronceros-Cardenas ${ }^{2}$, Bryan Valcarcel ${ }^{2}$, Miguel A. Arce-Huamani ${ }^{1,2}$, \\ Janina Bazalar-Palacios ${ }^{2,3}$, Jorge Ybaseta-Medina ${ }^{2,4}$, Carlo La Vecchia ${ }^{5}$ and Christian S. Alvarez ${ }^{6}$
}

\begin{abstract}
Background: Cervical cancer is the third leading cause of cancer-related death among Latin American women. Peru has the sixth highest mortality rate for cervical cancer in the region with regional variations. We aimed to determine overall and regional cervical cancer mortality rates and trends in Peru between 2008 and 2017.

Methods: We performed an ecological study on the number of deaths by cervical cancer in Peru. Deaths were extracted from the Peruvian Ministry of Health mortality database. Age-standardized mortality rates (ASMR) were estimated per 100,000 women-years using the world standard Segi population. We computed mortality trends using the Joinpoint regression program, estimating the annual percent change (APC). For spatial analysis, GeoDA software was used.

Results: Peru showed downward trends in the last decade (from 11.62 in 2008 to 9.69 in 2017 (APC = - 2.2, 95\% Cl: $-4.3,-0.1, p<0.05)$. According to regional-specific analysis, the highest ASMR was in the rainforest region, although this declined from 34.16 in 2008 to 17.98 in 2017 (APC $=-4.3,95 \% \mathrm{Cl}$ - - 7.2, - 1.3, p < 0.01). Concerning spatial analysis and clustering, the mortality rates from 2008 to 2017 showed a positive spatial autocorrelation and significant clustering (Moran's I: $0.35, p<0.001)$ predominantly in the neighboring North-East departments (Loreto, Ucayali, and San Martin).

Conclusions: Although mortality trends in the entire population are decreasing, mortality rates remain very high, mainly in the rainforest region. Our results encourage a need for further development and improvement of the current health care delivery system in Peru.
\end{abstract}

Keywords: Cervical cancer, Mortality, Trends, Epidemiology, Indigenous population, Peru

\section{Background}

Cervical cancer is the fourth leading cause of cancerrelated mortality among women worldwide [1] and the third in Latin America [2]. In 2018, GLOBOCAN reported an age-standardized mortality rate (ASMR) of $7.1 / 100,000$ women-years in South America, which is significantly higher compared to other regions such as Western Europe (2.1), North America (1.9), or

\footnotetext{
* Correspondence: jstorresroman@gmail.com

'Universidad Científica del Sur, Lima, Peru

${ }^{2}$ Latin American Network for Cancer Research (LAN-CANCER), Lima, Peru

Full list of author information is available at the end of the article
}

Australia/New Zealand (1.7) [1,3]. The highest mortality rates in Latin America were reported in Bolivia (21.0), Nicaragua (18.3), and Paraguay (15.7) [2].

The Pan American Health Organization (PAHO) has described that the variations of cervical cancer mortality rates among Latin American countries that correlate with the inequalities in each country [4]. Geographic location, access to health care, knowledge, education, cultural behaviors, and socioeconomic status are among the most prominent barriers for reducing mortality by cervical cancer [4]. In Peru, cervical cancer is the leading cause of death by cancer among women of reproductive

C C The Author(s). 2021 Open Access This article is licensed under a Creative Commons Attribution 4.0 International License, which permits use, sharing, adaptation, distribution and reproduction in any medium or format, as long as you give appropriate credit to the original author(s) and the source, provide a link to the Creative Commons licence, and indicate if changes were made. The images or other third party material in this article are included in the article's Creative Commons licence, unless indicated otherwise in a credit line to the material. If material is not included in the article's Creative Commons licence and your intended use is not permitted by statutory regulation or exceeds the permitted use, you will need to obtain permission directly from the copyright holder. To view a copy of this licence, visit http://creativecommons.org/licenses/by/4.0/ The Creative Commons Public Domain Dedication waiver (http://creativecommons.org/publicdomain/zero/1.0/) applies to the data made available in this article, unless otherwise stated in a credit line to the data. 
age [5]. The cervical cancer rates in the coastal region are substantially lower than other parts of the country due to higher socioeconomic status, and increased access to screening and specialized care [6]. Moreover, these rate disparities have important implications in Peru, where the uptake of early screening via the Pap smear (Pap) test is low [7], particularly in women living in rural areas [8].

The most recent governmental strategy called the "Plan Esperanza" [9], aims to decentralize health care delivery and reduce out-of-pocket expenditure for Peruvian citizens with low economic income and those living in vulnerable settings [9]. On the other hand, private health insurance provides cancer appointments and free screening to insurers [6].

Despite the efforts of Plan Esperanza to provide comprehensive coverage of cervical cancer screening, treatment, and medical care, this strategy is still restricted to urban areas [10]. Given the high and variability of the mortality rates among the Peruvian departments, we aimed to examine the overall and regional trends of cervical cancer mortality in Peru between 2008 and 2017. We further analyzed regional mortality trends in Peru.

\section{Methods}

\section{Design and study setting}

We performed an ecological study based on secondary data analysis using the Peruvian Ministry of Health (Known by its Spanish acronym, MINSA) mortality database. The data for mortality by cervical cancer was obtained from 2008 to 2017. Cervical cancer was identified by the code $\mathrm{C} 53$ according to the International Classification of Disease - 10th edition (ICD-10) [11]. MINSA is responsible for collecting mortality data from administrative records of private and public health facilities across the 25 departments of Peru. The information is available upon request on the MINSA online platform: http://www.minsa.gob.pe/portada/transparencia/ solicitud/.

MINSA collects mortality data at the national level from different sources, including all health establishment records, the National Registry of Identification and Civil Status, and the Public Ministry of Health [12]. The data collected include the number of deaths for each disease aggregated by 5 -year sex-specific age groups [12-14].

Peru is in the Andean region of South America and has a population of 31 million inhabitants distributed among three regions: coastal, highlands, and rainforest [15]. The coastal region spans $11.7 \%$ of the national territory, but it is the most populated region with approximately $56.3 \%$ of the total population of Peru. The highlands cover approximately $27.9 \%$ of the national territory and includes $29.7 \%$ of the population. Lastly, the rainforest is the largest region of the country, which accounts for $60.3 \%$ of the national territory but only contains $14 \%$ of the total population [15].

\section{Ethical considerations}

The current study utilized de-identified, publicly available data; therefore, ethical approval is not required. In order to obtain the raw data, an online form was completed through: https://www.minsa.gob.pe/portada/ transparencia/solicitud/.

\section{Correction of under-reporting}

The cause of death notification system throughout Peru is omissive [16]. The underreporting of deaths was corrected by year and per department of those registered by the Ministry of Health and death estimations by the National Statistics Institute (NSI) [16]. The variability coverage of the 2008 to 2017 registry of deaths was correct to determine the underreporting rate as reported in previous studies $[14,17]$ using the following formula:

$$
\mathrm{R}=100-(\mathrm{OD} / \mathrm{ED}) \times 100
$$

$\mathrm{R}=$ Underreporting rate

$\mathrm{OD}=$ number of deaths observed in each department.

$\mathrm{ED}=$ number of deaths estimated in each department.

\section{Statistical analysis}

After correcting the number of deaths, the agestandardized mortality rates (ASMR) were estimated per 100,000 women-years and adjusted to the world standard SEGI population [18] . The population denominators were obtained from census data in 2010, and 2015 conducted by NSI, which is responsible for regulating, planning, directing, coordinating, and supervising the official statistics of the country [19]. We examined the overall and regional mortality trends using the Joinpoint regression program version 4.7.0 [20], which identified significant trend change points and the rate of change (annual percent change [APC]) [21]. The significance levels utilized were based on the Monte Carlo permutation model and the calculation of the APC ratio utilizing the logarithm of the ratio [22, 23]. Additional analyses were performed to evaluate the overall, regional cervical cancer mortality trends pre-(2008-2011), and post-implementation (2012-2017) of Plan Esperanza.

GeoDA software was employed for the spatial analysis. We computed the highest and lowest ASMR of cervical cancer in the neighboring departments [24]. The map showed a spatial typology consisting of five categories as in previous studies in Peru [13, 15]: (i) ('high-high'), (ii) ('low-high'), (iii) ('low-low'), (iv) ('high-low'), and (v) 'not significant'. The Moran's I values ranged from - 1 to +1 . We used a reference distribution using 999 
random permutations to indicate statistical significance $(p<0.05)[24,25]$.

\section{Results}

Over 10 years, we identified an annual average of 990 deaths from cervical cancer, of which increased to 1729 deaths after correcting for underreporting of deaths. Similarly, the uncorrected mortality rates per 100,000 women-years increased from 6.8 to 11.8 in the entire population. When analyzed by region, the rainforest area showed the highest corrected average mortality rate (26.3 per 100,000 women-years), followed by the highlands (14.2 per 100,000 women-years), and the coastal region (9.5 per 100,000 women-years) (Table 1$)$.
Figure 1 displays the results of the joinpoint regression analysis for the uncorrected and corrected mortality rates in Peru and its' regions between 2008 and 2017. For the corrected rates, Peru experienced a significant downward trend from 11.62 in 2008 to 9.69 per 100,000 womenyears in $2017(\mathrm{APC}=-2.2,95 \%$ confidence interval $[\mathrm{CI}]$ : $-4.3,-0.1, p<0.05)$. Similarly, the coast and the rainforest region showed downward trends in cervical cancer mortality. The coast started a decreasing trend in 2010 $(\mathrm{APC}=-5.2,95 \% \mathrm{CI}:-8.9,-1.4, p<0.05)$, while the rainforest showed a reduction amongst the entire study period $(\mathrm{APC}=-4.3,95 \% \mathrm{CI}:-7.2,-1.3, p<0.05)$. The highlands were the only region with non-significant trends $(\mathrm{APC}=$ 0.1, 95\% CI: $-2.2,2.4, p=0.07$ ) (Fig. 1).

Table 1 Cervical cancer deaths and mortality rates in Peru according to geographical area from 2008 to 2017

\begin{tabular}{|c|c|c|c|c|}
\hline \multirow{2}{*}{$\begin{array}{l}\text { Geographical } \\
\text { areas }\end{array}$} & \multicolumn{2}{|c|}{ Annual deaths ${ }^{a}$} & \multicolumn{2}{|c|}{ Mortality rates $^{\mathrm{b}}$} \\
\hline & Uncorrected & Corrected & Uncorrected & Corrected \\
\hline Coast region & 654 & 942 & 6.6 & 9.5 \\
\hline Ancash & 25 & 54 & 4.6 & 9.8 \\
\hline Arequipa & 41 & 60 & 6.2 & 8.9 \\
\hline Callao & 36 & 43 & 6.7 & 8.2 \\
\hline Ica & 24 & 27 & 6.2 & 7.1 \\
\hline La Libertad & 73 & 100 & 8.4 & 11.6 \\
\hline Lambayeque & 77 & 95 & 12.1 & 15.0 \\
\hline Lima & 304 & 451 & 5.9 & 8.7 \\
\hline Moquegua & 9 & 13 & 10.3 & 16.0 \\
\hline Piura & 50 & 75 & 6.1 & 9.3 \\
\hline Tacna & 14 & 20 & 9.2 & 13.7 \\
\hline Tumbes & 2 & 4 & 2.5 & 4.8 \\
\hline Highlands region & 248 & 511 & 6.9 & 14.2 \\
\hline Apurimac & 8 & 20 & 4.1 & 10.2 \\
\hline Ayacucho & 14 & 34 & 5.0 & 12.4 \\
\hline Cajamarca & 32 & 81 & 5.0 & 12.6 \\
\hline Cusco & 29 & 68 & 4.8 & 11.2 \\
\hline Huancavelica & 12 & 25 & 6.8 & 14.0 \\
\hline Huanuco & 49 & 100 & 13.7 & 27.8 \\
\hline Junin & 63 & 108 & 11.0 & 18.6 \\
\hline Pasco & 10 & 21 & 9.0 & 19.5 \\
\hline Puno & 31 & 55 & 4.9 & 8.6 \\
\hline Rainforest region & 87 & 275 & 8.4 & 26.3 \\
\hline Amazonas & 8 & 29 & 4.8 & 18.5 \\
\hline Loreto & 28 & 136 & 7.8 & 37.4 \\
\hline Madre de Dios & 8 & 10 & 24.0 & 30.2 \\
\hline San Martin & 21 & 58 & 7.5 & 20.2 \\
\hline Ucayali & 23 & 43 & 11.4 & 21.4 \\
\hline Peru & 990 & 1729 & 6.8 & 11.8 \\
\hline
\end{tabular}

a Annual average of deaths for a 10-year period (2008-2017)

${ }^{\mathrm{b}}$ Age-standardized rates per 100,000 women-years 


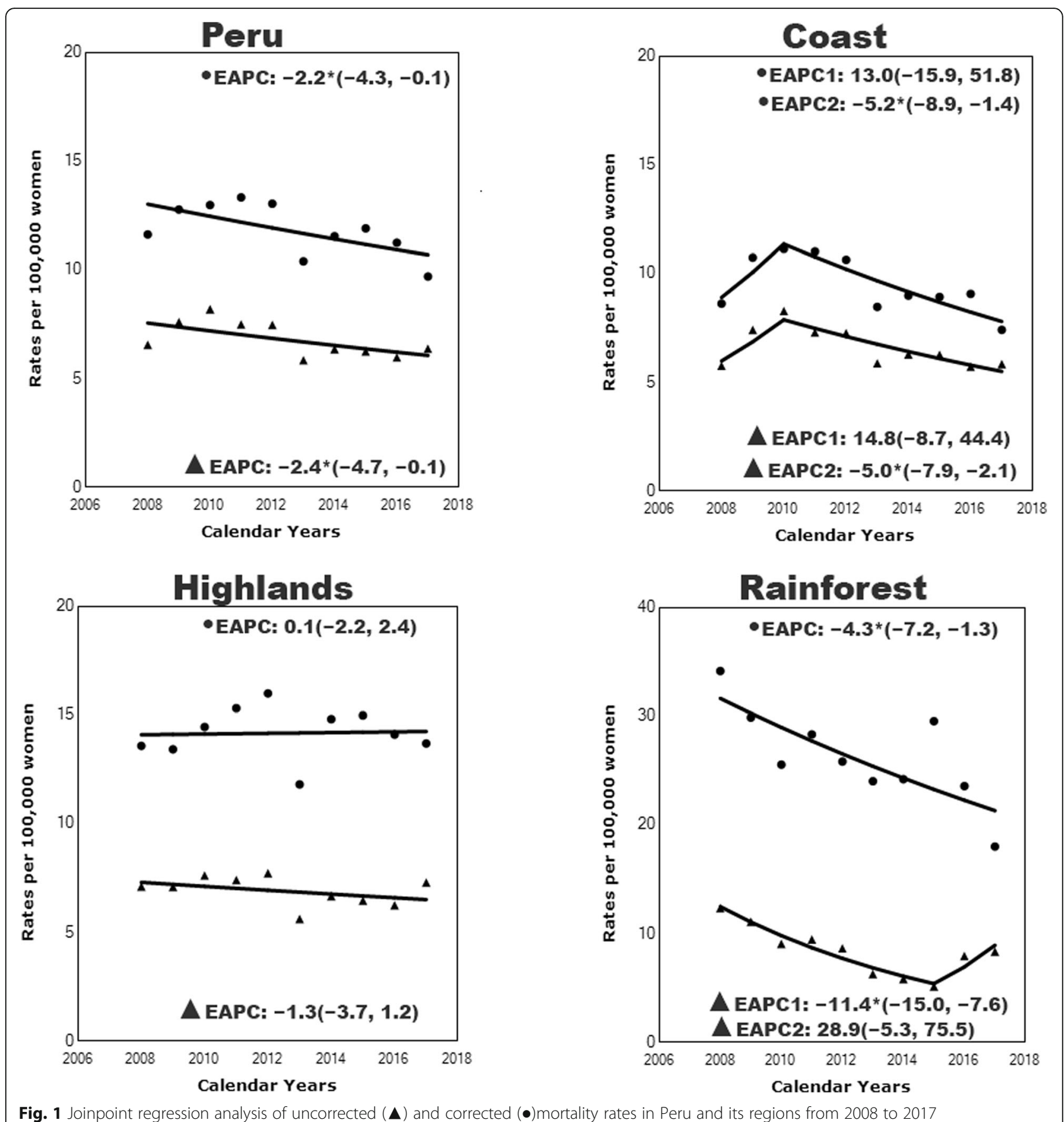

Table 2 shows the cervical cancer mortality rates (per 100,000 women-years), the percent change, and the estimated APC among Peruvian women between 2008 and 2017 in each geographical area. Three coastal departments showed significant downward trends: Arequipa, from 8.82 to 6.10 (31\% reduction; $\mathrm{APC}=-3.9 ; 95 \% \mathrm{CI}$ : - 8.1, $0.4 ; p<0.05$ ); Lima, from 8.66 to 6.58 (24\% reduction; $\mathrm{APC}=-3.6,95 \% \mathrm{CI}:-6.3,-0.8 ; p<0.05)$; and Piura, from 10.26 to 5.97 (42\% reduction; $\mathrm{APC}=-4.3$,
95\% CI: $-7.7,-0.7 ; p<0.05)$. In addition, Ucayali was the only department of the rainforest region that showed a significant reduction in the mortality rate from 29.53 in 2008 to 13.60 in 2017 (54\% reduction; $\mathrm{APC}=-12.9$, 95\% CI: $-21.8,-3.2 ; p<0.05)$. No significant downward trends were observed in the highland departments (Table 2 and Fig. 2).

Table 2. Cervical cancer mortality rates (per 100,000 women-years), data availability, percent change, and 
Table 2 Cervical cancer mortality rates (per 100,000 women-years), data availability, percent change, and estimated annual percent change and the corresponding 95\% confidence intervals in Peruvian women between 2008 and 2017

\begin{tabular}{|c|c|c|c|c|c|}
\hline \multirow{2}{*}{$\begin{array}{l}\text { Geographical } \\
\text { areas }\end{array}$} & \multicolumn{5}{|c|}{ Cervical cancer mortality rates (per 100,000 women-years) } \\
\hline & 2008 & 2017 & $\%$ change $(2017 / 2008)$ & EAPC & $95 \% \mathrm{Cl}$ \\
\hline \multicolumn{6}{|l|}{ Coast region } \\
\hline Ancash & 8.85 & 7.05 & -20 & -4.9 & $-9.8,0.2$ \\
\hline Arequipa & 8.82 & 6.10 & -31 & $-3.9^{*}$ & $-8.1,0.4$ \\
\hline Callao & 4.25 & 5.93 & 40 & 0.4 & $-7.1,8.6$ \\
\hline Ica & 7.22 & 8.14 & 13 & 1.9 & $-4.4,8.6$ \\
\hline La Libertad & 11.77 & 11.46 & -3 & -3.0 & $-6.7,0.7$ \\
\hline Lambayeque & 5.02 & 11.32 & 125 & 5.1 & $-5.1,16.4$ \\
\hline Lima & 8.66 & 6.58 & -24 & $-3.6^{*}$ & $-6.3,-0.8$ \\
\hline Moquegua & 16.74 & 10.87 & -35 & -8.5 & $-16.6,0.3$ \\
\hline Piura & 10.26 & 5.97 & -42 & $-4.3^{*}$ & $-7.7,-0.7$ \\
\hline Tacna & 9.45 & 16.20 & 71 & 3.5 & $-3.0,10.5$ \\
\hline Tumbes & 4.86 & 2.26 & -53 & -8.1 & $-18.7,3.9$ \\
\hline \multicolumn{6}{|l|}{ Highlands region } \\
\hline Apurimac & 5.61 & 12.84 & 129 & 6.9 & $-8.0,24.3$ \\
\hline Ayacucho & 10.80 & 8.21 & -24 & -0.8 & $-9.4,8.6$ \\
\hline Cajamarca & 8.81 & 9.62 & 9 & -4.0 & $-11.9,4.4$ \\
\hline Cusco & 10.63 & 11.94 & 12 & 1.3 & $-2.1,4.9$ \\
\hline Huancavelica & 12.23 & 18.39 & 50 & -0.5 & $-9.0,8.8$ \\
\hline Huanuco & 25.70 & 22.67 & -12 & 0.4 & $-3.3,4.2$ \\
\hline Junin & 21.76 & 22.09 & 2 & -0.3 & $-4.8,4.3$ \\
\hline Pasco & 13.20 & 9.09 & -31 & -2.6 & $-13.9,10.1$ \\
\hline Puno & 11.37 & 9.42 & -17 & 2.3 & $-3.9,8.9$ \\
\hline \multicolumn{6}{|l|}{ Rainforest region } \\
\hline Amazonas & 30.04 & 23.53 & -22 & -2.4 & $-17.4,15.3$ \\
\hline Loreto & 49.29 & 18.95 & -62 & -5.4 & $-13.1,3.1$ \\
\hline Madre de Dios & 55.76 & 7.40 & -87 & -6.7 & $-19.6,8.3$ \\
\hline San Martin & 19.35 & 17.46 & -10 & 0.9 & $-3.2,5.3$ \\
\hline Ucayali & 29.53 & 13.60 & -54 & $-12.9^{*}$ & $-21.8,-3.2$ \\
\hline
\end{tabular}

* significantly different from $0(p<0.05)$

$\mathrm{APC}$, estimated annual percent change; Cl: confidence interval

estimated annual percent change and the corresponding 95\% confidence intervals in Peruvian women between 2008 and 2017.

Table 3 shows cervical cancer mortality trends between 2008 and 2011 (Pre-Plan Esperanza) and 20122017 (Post-Plan Esperanza) in Peru and its regions. The mortality rates in Peru increased by $15 \%$ between 2008 and 2011 (except in the rainforest region) but declined considerably by $26 \%$ from 2012 to 2017 . Similarly, the mortality rate in the coastal region increased by $28 \%$ between 2008 and 2011 but decreased by 30\% between 2012 and 2017. In the highlands' region, mortality increased by $13 \%$ between 2008 and 2011, but declined by 14\% after 2012 and 2017, while the rainforest region showed a reduction of 17\% between 2008 and 2011. Furthermore, 30\% of a reduction between 2012 and 2017. None of these outcomes were statistically significant.

Table 3. Cervical cancer mortality trends (per 100,000 women-years), between 2008 and 2011 (Pre- Plan Esperanza) and 2012-2017 (Post- Plan Esperanza) in Peru and its regions.

Figure 3 illustrates the spatial distribution for cervical cancer in Peruvian women between 2008 and 2017. The highest mortality rates were observed in the rainforest departments including Loreto, Ucayali, and Madre de Dios (ASMR $\geq 20$ per 100,000 women-years), while the coastal departments had the lowest mortality rates. In reference to the spatial analysis and clustering, the 


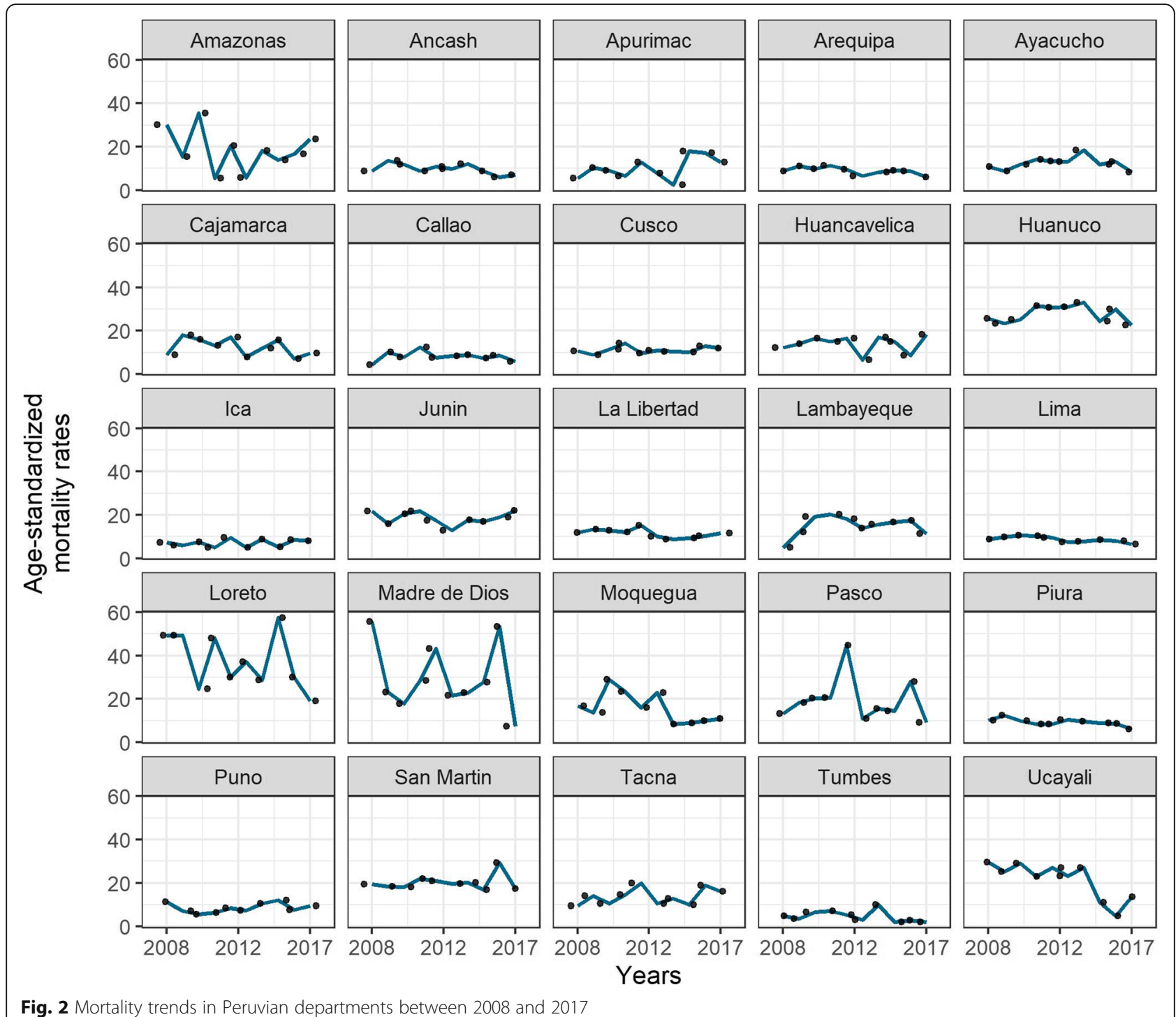

mortality rates from 2008 to 2017 showed a positive spatial autocorrelation and significant clustering (Moran's I: $0.35, p<0.001)$. The departments with the highest cervical cancer mortality rates were in the neighboring North-East departments (Loreto, Ucayali, and San Martin) as shown in Fig. 4.

\section{Discussion}

We found a decrease in cervical cancer mortality rates in Peru from 2008 to 2017. Despite these findings, Peru still has higher mortality rates compared to other Latin American countries such as Argentina (8.4), Brazil (7.3), Chile (6.0), Colombia (8.0), and Mexico (8.1) [26].

Table 3 Cervical cancer mortality trends (per 100,000 women-years), between 2008 and 2011 (Pre- Plan Esperanza) and 2012-2017 (Post- Plan Esperanza) in Peru and its regions

\begin{tabular}{|c|c|c|c|c|c|c|c|c|c|c|}
\hline \multirow{3}{*}{$\begin{array}{l}\text { Geographical } \\
\text { areas }\end{array}$} & \multicolumn{10}{|c|}{ Cervical cancer mortality rates (per 100,000 women-years) } \\
\hline & \multicolumn{5}{|c|}{ Pre-Plan Esperanza } & \multicolumn{5}{|c|}{ Post- Plan Esperanza } \\
\hline & 2008 & 2011 & \%change & APC & $95 \% \mathrm{Cl}$ & 2012 & 2017 & \%change & APC & $95 \% \mathrm{Cl}$ \\
\hline Peru & 11.62 & 13.33 & 15 & 4.4 & $-1.1,10.1$ & 13.04 & 9.69 & -26 & -3.4 & $-9.1,2.6$ \\
\hline Coast region & 8.61 & 11.01 & 28 & 8.0 & $-8.1,27.1$ & 10.63 & 7.40 & -30 & -4.5 & $-9.9,1.3$ \\
\hline Highlands region & 13.58 & 15.31 & 13 & 4.4 & $-1.3,10.5$ & 15.99 & 13.69 & -14 & -0.7 & $-8.0,7.3$ \\
\hline Rainforest region & 34.16 & 28.33 & -17 & -6.9 & $-22.5,11.8$ & 25.83 & 17.98 & -30 & -4.7 & $-13.8,5.5$ \\
\hline
\end{tabular}




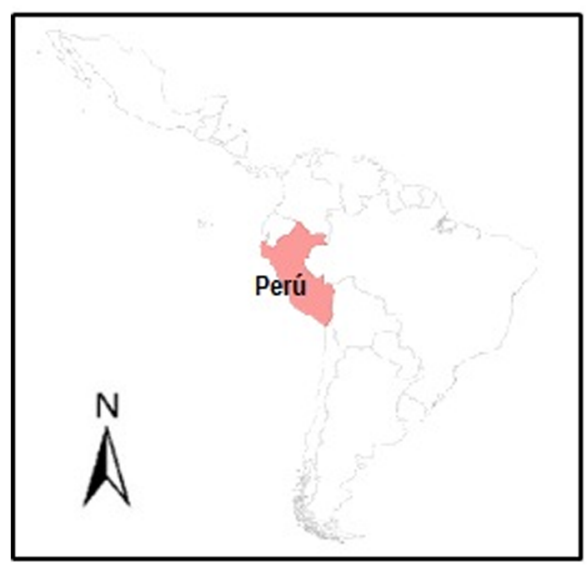

Mortality rates per 100,000 women
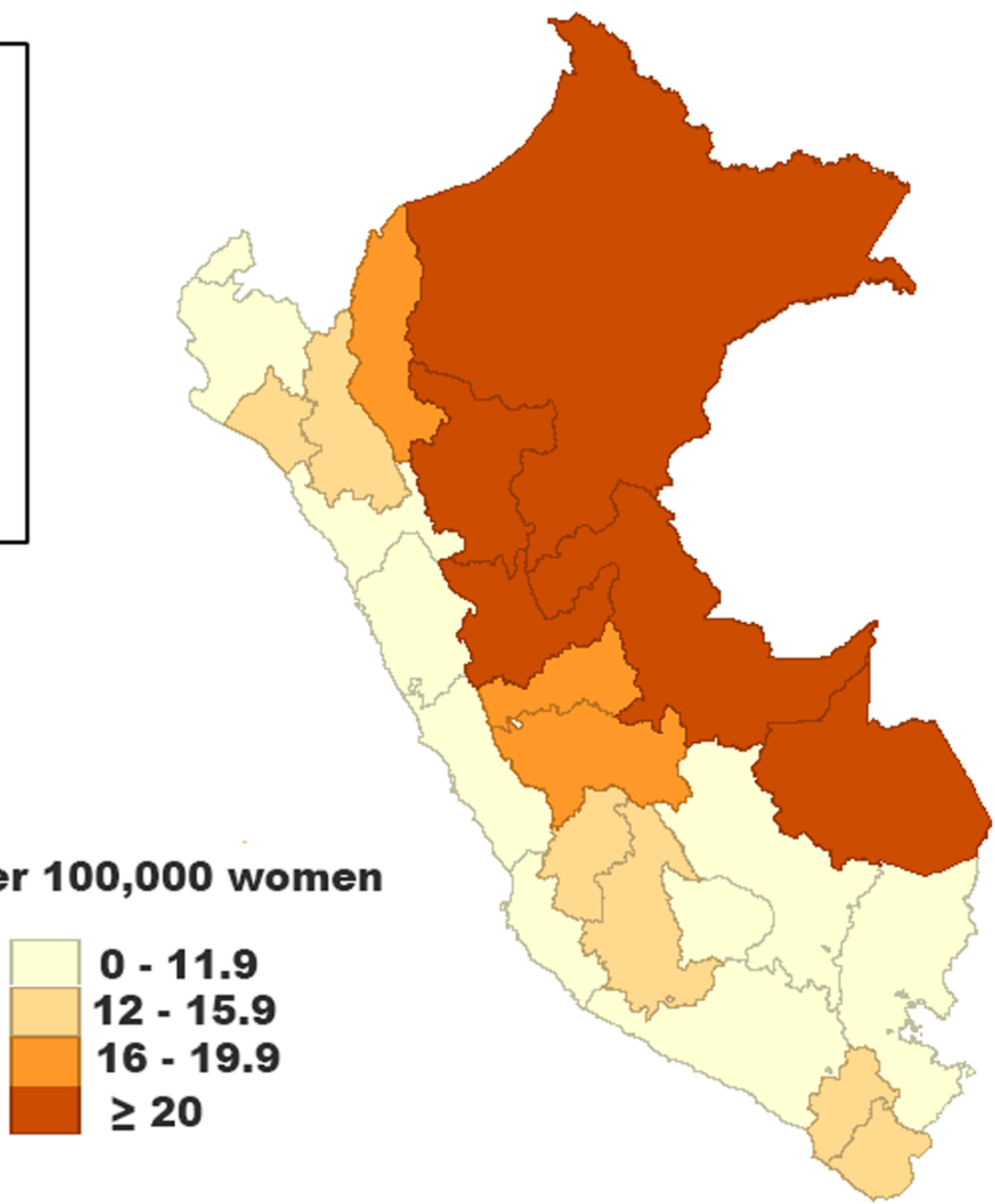

Fig. 3 Spatial distribution of age-standardized mortality rates for cervical cancer in Peru from 2008 to 2017. Map created using GEODA version 1.14.0. Available at: https://geodacenter.github.io/index.html

Between 2002 and 2018, cervical cancer mortality rates in Latin America decreased from 12.9 to 7.1 per 100,000 women [1, 27], with a further reduction in Brazil, Colombia, and Mexico. However, these mortality rates are higher than those of European countries [28-30], with rates of about 3 deaths per 100,000 women.

The downward mortality trends in cervical cancer could be rationalized by the continued efforts of the Peruvian government to reduce the burden of this disease. In 2007, "The concerted health plan" [31] was approved to reduce mortality by cervical cancer, promote prevention, screening, early diagnosis, and implement protocols to improve primary care delivery [31]. Later, in 2012, Plan Esperanza was implemented to expand health coverage and to provide comprehensive cancer health services to vulnerable populations, providing an early diagnosis of cancer (including cervical cancer) to reduce mortality rates [9]. In fact, Plan Esperanza has played an important role on decreasing the burden of mortality of cervical cancer in Peru. Nevertheless, the rainforest region has the highest cervical cancer mortality rates. There are several reasons are related to this outcome. The rainforest has a high density of indigenous women [32]. A study in Latin American indigenous women [33] showed a higher risk of death from cervical cancer, which could be explained by the lower detection rate of early-stage cervical cancer and barriers to access treatment [10, 33-35]. In addition, the socioeconomic disparities, lack of access to health care services, and low education in the rainforest region [36], have and continue to create a setting with a lack of knowledge, and poor education on cancer prevention, resulting in poor adherence to treatment and even rejection of screening $[34,35,37]$. These factors compromise the overall population health and prevent further reductions of mortality rates. As a result, there is a need to develop community 


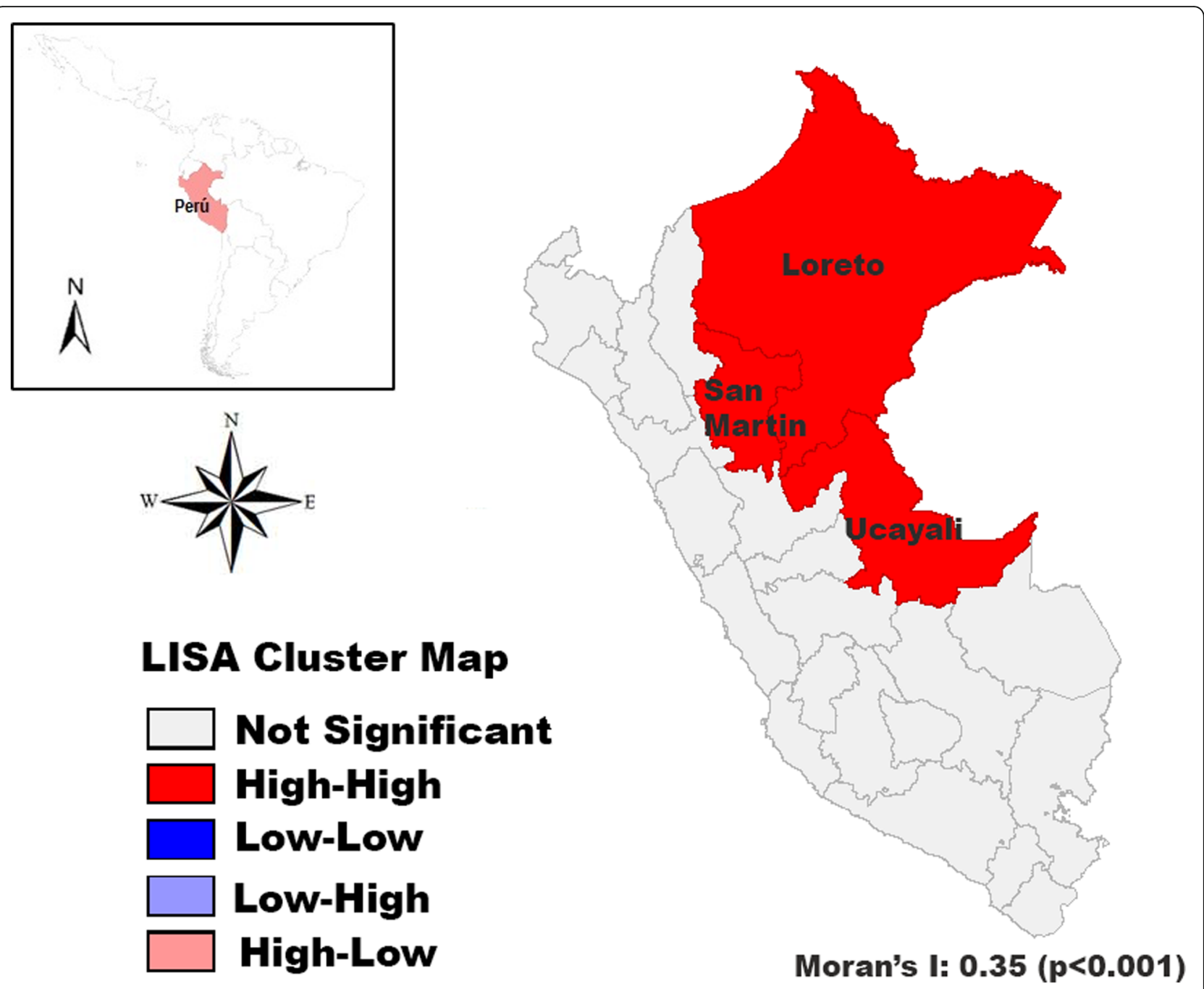

Fig. 4 Spatial auto-correlation for cervical cancer mortality rates for the period 2008-2017. Map created using GEODA version 1.14.0. Available at: https://geodacenter.github.io/index.html

programs for indigenous women and strengthen decentralization processes to obtain favorable mortality outcomes.

The coastal departments had the lowest mortality rates, and the overall region showed significant downward trends. The greater access to health care services and socioeconomic income of the population in this region further explains the findings of this study [3, 7]. Similarly, studies in Brazil and the United States reported a lower mortality rates in states with both higher human development indexes and economic incomes [38, 39]. Nevertheless, it is to be expected that rapid access to healthcare facilities and the availability of therapy would result in lower mortality trends in the coastal region.

Since the implementation of Plan Esperanza, the coverage for cervical cancer screening, including cytology (Papanicolaou smear or liquid-based cytology), cervical visual inspection with acetic acid, or cryotherapy, colposcopy, and molecular human papillomavirus tests has been made available in Peru [9]. Therefore, a higher rate of pre-neoplastical lesion detection in combination with access, prompted treatment in the coastal region, which will lead to a decrease in mortality rates.

However, this scenario is not feasible in the rainforest and highlands regions, due to the geographical barriers, are one of the principal limitations to accessing screening procedures and treatment. Despite the efforts to decentralize health care, this has not reached most of the population in the highlands. This explains the nonstable trend in these regions of our analysis, in contrast to the coastal and rainforest regions which showed a downward trend that has been more pronounced since the implementation of the Plan Esperanza (Table 3). Moreover, the remote rural areas of the coast departments generate high socioeconomic disparities and limitations in health care practice (e.g., supplies for Pap 
smears, poor standardization of procedures, inadequate training of health personnel, unavailability of appropriate therapies, high treatment costs, inefficient management of information systems, and delivery of results) [40]. Consequently, the preventive effect of prompt cancer detection and adequate treatment of patients in urban areas is hindered by poor health delivery in rural areas. These shortcomings affect preventive strategies and represent a limitation of decreasing mortality rates of cervical cancer in Peru.

\section{Strengths and limitations}

This study is the first to report the regional mortality rates and trends by cervical cancer in the last decade in Peru. The results of this study provide a perspective of the current trends of cervical cancer mortality in the country and the impact of programs to reduce the burden of cervical cancer mortality such as the Plan Esperanza. The main limitation of this study is the underreporting of deaths, and the possibility that a proportion of cervical cancer deaths are registered as death by uterine cancer or of unspecified origin. In regions with poor health and communication systems, such as the department of Loreto, the rate of omission of death registration is as high as $78 \%$. However, we corrected the underreporting and estimated reliable mortality rates of the female population across the country [16].

\section{Conclusion}

In conclusion, although our results found decreasing in the mortality trends in the entire population, the overall rates by cervical cancer remain high, mainly in the rainforest region. Our results demonstrate the need for further development and the improvement of the current health care delivery systems for the most affected populations, and the provision of a wide range of health coverage to vulnerable women.

\section{Abbreviations}

APC: Annual percent change; ASMR: Age-standardized mortality rates

\section{Acknowledgments}

Not applicable.

\section{Authors' contributions}

Conceived and designed the idea: JSTR, LRC. Had full access to all the data in the study and take responsibility for the integrity of the data and the accuracy of the data analysis: JSTR, JYM. Contributed to the writing of the manuscript: JSTR, LRC, BV, MAH, JBP, JYM, CL, CSA. Contributed to the statistical analysis: JSTR, BV, MAH. Critical revision of the manuscript: JYM, CSA and CLV. Approval of the submitted and final version: JSTR, LRC, BV, MAH, JBP, JYM, CL, CSA.

\section{Funding}

No funding was received for this study.

\section{Availability of data and materials}

The datasets generated and/or analyzed during the current study are available prior request in the following link: http://www.minsa.gob.pe/ portada/transparencia/solicitud/

\section{Ethics approval and consent to participate}

The ethical approval and consent of the participant were not necessary since this study involved the use of a de-identified publicly available data. More details in Ethical considerations section.

\section{Consent for publication}

Not applicable.

\section{Competing interests}

The authors declare that they have no competing interests.

\section{Author details}

${ }^{1}$ Universidad Científica del Sur, Lima, Peru. ${ }^{2}$ Latin American Network for Cancer Research (LAN-CANCER), Lima, Peru. ${ }^{3}$ Universidad Católica Los Ángeles de Chimbote, Instituto de Investigación, Chimbote, Peru. ${ }^{4}$ Facultad de Medicina Humana, Universidad Nacional San Luis Gonzaga, Ica, Peru. ${ }^{5}$ Department of Clinical Sciences and Community Health, Università degli Studi di Milano, 20133 Milan, Italy. ${ }^{6}$ Division of Cancer Epidemiology and Genetics, National Cancer Institute, Rockville, MD, USA.

Received: 2 September 2020 Accepted: 19 January 2021

Published online: 26 January 2021

\section{References}

1. Bray F, Ferlay J, Soerjomataram I, Siegel RL, Torre LA, Jemal A. Global cancer statistics 2018: GLOBOCAN estimates of incidence and mortality worldwide for 36 cancers in 185 countries. CA Cancer J Clin. 2018:68(6):394-424.

2. Capote Negrin LG. Epidemiology of cervical cancer in Latin America. Ecancermedicalscience. 2015:9:577.

3. Arbyn M, Weiderpass E, Bruni L, de Sanjosé S, Saraiya M, Ferlay J, Bray F. Estimates of incidence and mortality of cervical cancer in 2018: a worldwide analysis. Lancet Glob Health. 2020;8(2):e191-203.

4. Pan American Health Organization. A situational analysis of cervical cancer in Latin America and the Caribbean. 2004. Available from: https://iris.paho. org/bitstream/handle/10665.2/766/92\%2075\%2012531\%207.pdf?sequence= 1 \&isAllowed=y.

5. Piñeros M, Ramos W, Antoni S, Abriata G, Medina LE, Miranda JJ, Payet E, Bray F. Cancer patterns, trends, and transitions in Peru: a regional perspective. Lancet Oncol. 2017;18(10):e573-86.

6. Aguilar A, Pinto JA, Araujo J, Fajardo W, Bravo L, Pinillos L, Vallejos C. Control of cervical cancer in Peru: current barriers and challenges for the future. Mol Clin Oncol. 2016:5(2):241-5.

7. Paz Soldan VA, Lee FH, Carcamo C, Holmes KK, Garnett GP, Garcia P. Who is getting pap smears in urban Peru? Int J Epidemiol. 2008;37(4):862-9.

8. Barrionuevo-Rosas $L$, Palencia $L$, Borrell $C$. How does type of health insurance affect receipt of pap testing in Peru? Rev Panam Salud Pública. 2013;34(6):393-404

9. Vidaurre T, Santos C, Gómez H, Sarria G, Amorin E, López M, Regalado $\mathrm{R}$, Manrique J, Tarco D, Ayestas C. The implementation of the plan Esperanza and response to the imPACT review. Lancet Oncol. 2017; 18(10):e595-606.

10. Nevin PE, Garcia PJ, Blas MM, Rao D, Molina Y. Inequities in cervical cancer care in indigenous Peruvian women. Lancet Glob Health. 2019:7(5):e556-7.

11. World Health Organization. International Classification of Disease and Related Health Problems: 10th Revision, vol. 1. Geneva: World Health Organization; 1992.

12. Ruiz EF, Torres-Roman JS, Servan SA, Martinez-Herrera JF, Arce-Huamani MA, Carioli G, La Vecchia C. Trends and geographic pattern of stomach cancer mortality in Peru. Cancer Epidemiol. 2019;58:193-8.

13. Torres-Roman JS, Ruiz EF, Martinez-Herrera JF, Mendes Braga SF, Taxa L, Saldaña-Gallo J, Pow-Sang MR, Pow-Sang JM, La Vecchia C. Prostate cancer mortality rates in Peru and its geographical regions. BJU Int. 2019;123(4):595-601.

14. Torres-Roman JS, Gomez-Rubio V, Sanchez-Trujillo L, Delgado-Rosas E, Puche-Vergara F, Sanz-Anquela JM, et al. Geographic study of mortality due 
to mesothelioma in Peru and its evolution. Cancer Epidemiol. 2020;68: 101791.

15. Torres-Roman JS, Urrunaga-Pastor D, Avilez JL, Helguero-Santin LM, Malaga G. Geographic differences in overweight and obesity prevalence in Peruvian children, 2010-2015. BMC Public Health. 2018;18(1):353.

16. Ministerio de Salud. Oficina General de Estadística e Informática. Mortalidad General en el Perú 2007-2011. Available in : http://bvs.minsa.gob.pe/local/ minsa/2722.pdf. [Cited March 1, 2020].

17. Torres-Roman JS, Martinez-Herrera JF, Carioli G, Ybaseta-Medina J, Valcarcel B, Pinto JA, Aguilar A, McGlynn KA, La Vecchia C. Breast cancer mortality trends in Peruvian women. BMC Cancer. 2020;20(1):1-9.

18. World Health Organization. Age standardization of rates: a new who standard. 2011. Available from: http://www.who.int/healthinfo/paper31.pdf?ua=1.

19. Instituto Nacional de Estadistica e Informatica. Boletín de Análisis Demográfico № 37. Perú: Estimaciones y Proyecciones de Población por departamento, sexo y grupos quinquenales de edad, 1995-2025. Available in: http://proyectos.inei.gob.pe/web/biblioineipub/bancopub/Est/Lib0846/ index.htm. [Cited March 1, 2020].

20. National Cancer Institute. Joinpoint regression program. Available in: https:// surveillance.cancer.gov/help/joinpoint. Accesed 4 Apr 2020.

21. Howlader N, Noone A, Krapcho M, Miller D, Bishop K, Altekruse S, Kosary C, Yu M, Ruhl J, Tatalovich Z. SEER Cancer statistics review, 1975-2013, National Cancer Institute. Bethesda, MD. In; 2016.

22. Kim HJ, Fay MP, Feuer EJ, Midthune DN. Permutation tests for joinpoint regression with applications to cancer rates. Stat Med. 2000:19(3):335-51.

23. Kim HJ, Fay MP, Yu B, Barrett MJ, Feuer EJ. Comparability of segmented line regression models. Biometrics. 2004;60(4):1005-14.

24. Anselin L, Syabri I, Kho Y. GeoDa: an introduction to spatial data analysis. Geogr Anal. 2006;38(1):5-22.

25. Goovaerts P, Jacquez GM. Detection of temporal changes in the spatial distribution of cancer rates using local Moran's I and geostatistically simulated spatial neutral models. J Geogr Syst. 2005;7(1):137-59.

26. Negrin LGC. Epidemiology of cervical cancer in Latin America. ecancermedicalscience. 2015;9.

27. Parkin DM, Bray F, Ferlay J, Pisani P. Global cancer statistics, 2002. CA Cancer J Clin. 2005;55(2):74-108.

28. Malvezzi M, Bertuccio P, Levi F, La Vecchia C, Negri E. European cancer mortality predictions for the year 2013. Ann Oncol. 2013;24(3): 792-800.

29. Ferlay J, Parkin D, Steliarova-Foucher E. Estimates of cancer incidence and mortality in Europe in 2008. Eur J Cancer. 2010;46(4):765-81.

30. Carioli G, Bertuccio P, Boffetta P, Levi F, La Vecchia C, Negri E, Malvezzi M. European cancer mortality predictions for the year 2020 with a focus on prostate cancer. Ann Oncol. 2020.

31. Ministerio de Salud. Resolución Ministerial № 589-2007 /MINSA. Plan Nacional Concertado de Salud. Peru. [Cited April 20, 2020]. Available in: https://cdn.www.gob.pe/uploads/document/file/440948/plan-nacionalconcertado-de-salud.pdf.

32. Aparicio PM. Pueblos Indigenas de la Amazonia. [ Cited June 17, 2020]. Available in: https://atlasanatomiaamazonia.uab.cat/pdfs/ PueblosIndigenasAmazoniaPeruana.pdf.

33. Moore SP, Forman D, Piñeros M, Fernández SM, de Oliveira SM, Bray F. Cancer in indigenous people in Latin America and the Caribbean: a review. Cancer Med. 2014;3(1):70-80.

34. Agurto I, Bishop A, Sanchez G, Betancourt Z, Robles S. Perceived barriers and benefits to cervical cancer screening in Latin America. Prev Med. 2004; 39(1):91-8.

35. Gottschlich A, Ochoa P, Rivera-Andrade A, Alvarez CS, Montano CM, Camel C, Meza R. Barriers to cervical cancer screening in Guatemala: a quantitative analysis using data from the Guatemala demographic and health surveys. Int J Public Health. 2020;65(2):217-26.

36. Wang $X-Q$, Terry PD, Yan H. Review of salt consumption and stomach cancer risk: epidemiological and biological evidence. World J Gastroenterol. 2009;15(18):2204

37. Ditzian LR, David-West G, Maza M, Hartmann B, Shirazian T, Cremer M. Cervical cancer screening in low-and middle-income countries. Mt Sinai J Med. 2011;78(3):319-26.

38. Yoo W, Kim S, Huh WK, Dilley S, Coughlin SS, Partridge EE, Chung Y, Dicks $V$, Lee J-K, Bae S. Recent trends in racial and regional disparities in cervical cancer incidence and mortality in United States. PLoS One. 2017;12(2).
39. Meira KC, Silva GWS, dos Santos J, Guimarães RM, de Souza DLB, Ribeiro GPC, Dantas ESO, Carvalho JBL, Jomar RT, Simões TC. Analysis of the effects of the age-period-birth cohort on cervical cancer mortality in the Brazilian northeast. PLoS One. 2020;15(2):e0226258.

40. Paz-Soldán VA, Bayer AM, Nussbaum L, Cabrera L. Structural barriers to screening for and treatment of cervical cancer in Peru. Reprod Health Matters. 2012;20(40):49-58.

\section{Publisher's Note}

Springer Nature remains neutral with regard to jurisdictional claims in published maps and institutional affiliations.
Ready to submit your research? Choose BMC and benefit from:

- fast, convenient online submission

- thorough peer review by experienced researchers in your field

- rapid publication on acceptance

- support for research data, including large and complex data types

- gold Open Access which fosters wider collaboration and increased citations

- maximum visibility for your research: over $100 \mathrm{M}$ website views per year

At $\mathrm{BMC}$, research is always in progress.

Learn more biomedcentral.com/submissions 